\title{
Regulation of Child Criminal Action Through Diversion in the Child Criminal System
}

\author{
Kiki Oditya Hernawarman ${ }^{1}$, Faisal Santiago ${ }^{2}$ \\ \{odityakiki84@gmail.com¹, faisalsantiago@borobudur.ac.id²\} \\ Universitas Borobudur, Jakarta, Indonesia ${ }^{1,2}$
}

\begin{abstract}
This research relates to the regulation of the handling of juvenile crimes through redirection in the adolescent criminal equity framework. The examination strategy utilized is standardizing juridical utilizing auxiliary information. The outcomes show that the guideline of taking care of adolescent violations through redirection in the adolescent criminal equity framework is contained in Article 5 section (1) of Law Number 11 of 2012 concerning Juvenile Justice, specifically the helpful equity approach which is thought to be the latest shift from different models and components is right now working in the criminal equity framework in managing criminal cases, one of which is youngster wrongdoing. However, in practice, there are still court decisions that impose prison sentences on children, even though the crimes committed by the child can be applied with social work penalties or coaching that prioritizes the rights of children to return to being good children..
\end{abstract}

Keywords: Child; Diversion; Criminal Justice System

\section{Introduction}

Children[1] are essential for the more youthful age as one of the HR who are the potential and replacement to the beliefs of the country's battle, which play an essential part and have exceptional qualities and attributes, require direction and insurance to guarantee actual development and advancement, mental, and social all in all, amicable, consistence, and adjusted. For kids who are associated with perpetrating a wrongdoing, it is feasible to be confined in the State Detention Center, house, or city. Law Number 11 of 2012 concerning Juvenile Justice (henceforth alluded to as the Juvenile Justice Act) doesn't deny officials from confining a kid when the case is inspected. Detainment is completed after truly thinking about the interests of the kid and the interests of the local area.

At present, the Juvenile Justice Law has been established, the prelude expressed that youngsters are a command and gift from God Almighty who has pride and worth overall individual; To keep up with their nobility, kids reserve the option to exceptional assurance, particularly legitimate insurance [2] in the judicial system.

Indonesia as a state party to the Convention on the Rights of the Child (Convention on the Rights of the Child) that manages the rule of lawful security [3] for youngsters ought to give unique assurance to kids in struggle with the law. Kids as culprits of wrongdoings are additionally qualified for insurance as far as human rights.4 In the Indonesian constitution, 
specifically the 1945 Constitution [5], there are 4 (four) articles that guarantee several human rights, namely freedom of association and freedom of association. gather; liberty of thought and expression; the right to work and live; and liberty in embracing and practicing religion.[6]

The relationship between the Juvenile Justice Act and the Criminal Procedure Code (Law Number 8 of 1981 concerning the Criminal Procedure Code) and the Criminal Code (Book of Criminal Law) is a particular legal relationship and general law. The Juvenile Justice Act is a special law (lex specialist), while the Criminal Procedure Code and the Criminal Code are common law (lex generalis). As a particular law, the Juvenile Justice Act has specifically regulated the procedural law from the level of investigation about how to examine the court.

The Juvenile Justice Law also specifically regulates material criminal provisions.[7] Regarding the material criminal provisions in the Juvenile Justice Law, it turns out that the provisions of Article 45, Article 46, and Article 47 of the Criminal Code have been revoked, so that now these provisions are no longer valid.[8]

In view of this, the discipline for culprits of youngster violations doesn't then accomplish equity for the people in question, taking into account that the other hand, it actually leaves its concerns that are not settled despite the fact that the culprits have been rebuffed. Seeing the standards on youngster insurance, particularly the rule of focusing on the wellbeing of kids, a cycle for settling kid cases is required through a remedial equity component.

The way of thinking of the foundation of remedial equity is that the organization of discipline isn't a method for tackling kids' matters since it is unequivocally in it that infringement of kids' freedoms are inclined to happen. The helpful equity instrument is a discourse among the Indonesian public referred to better as "consultations for agreement" so the idea of remedial equity turns into an essential thought in settling criminal cases carried out by youngsters.

It is as regulated in Article 5 paragraph (1) of the Juvenile Justice Law which stipulates that juvenile justice must prioritize restorative justice.[9] One model of restorative justice is the application of diversion in juvenile justice.

Redirection or redirection was first advanced as jargon in the report on the execution of adolescent equity presented by the President of the Australian Criminal Commission (President Crime Commission) in the United States in 1960. Prior to the presentation of the term redirection, the act of redirection as redirection had existed before 1960 set apart by the foundation of kids' courts before the nineteenth century, specifically the redirection of the proper criminal equity framework and the formalization of police advised.[10]

In Indonesia, the provisions regarding the implementation of diversion can be seen from the discretionary arrangements given to law enforcement officers in handling child cases, starting from the adjustment in the Criminal Procedure Code and the specific arrangements for law enforcement officers themselves. Before the enactment of the Juvenile Justice Act, the implementation of diversion by law enforcement officers was initially based on discretionary authority.

According to the Legal Dictionary, discretion means freedom to make decisions in every situation he faces according to his own opinion.[11] Discretion is needed as a complement to the principle of legality, namely the principle of law that states that every action or act of state administration must be based on the provisions of the law, but the law cannot regulate all kinds of position cases in the practice of everyday life.

Moreover, it is managed in the Juvenile Justice Law and Supreme Court Regulation Number 4 of 2014 concerning Guidelines for Implementing Diversion in the Juvenile Criminal Justice System. As per Article 1 point 7 of the Juvenile Justice Act, redirection is the exchange of the settlement of kids' cases from the criminal equity interaction to processes 
outside the criminal equity framework, which plans to accomplish harmony among casualties and kids, resolve youngster cases outside the legal cycle, keep kids from hardship of autonomy, urge the local area to partake, and impart an awareness of certain expectations in kids.

According to Article 1 point 1 of the Regulation of the Supreme Court Number 4 of 2014 it is stated that diversion deliberation is a discussion between parties involving the child and his/her parents/guardians, victims and/or their parents/guardians, community advisors, professional social workers, representatives and other parties that involved in reaching a diversion agreement through a restorative justice approach, while the Facilitator is a judge appointed by the Chief Justice to handle the case of the child concerned.

Article 2 of the Supreme Court Regulation Number 4 of 2014 clarifies that redirection is applied to kids who are 12 (twelve) years of age yet not yet 18 (eighteen) years of age, or 12 (twelve) years of age despite the fact that they have been hitched however are not yet 18 (eighteen) years of age who are associated with carrying out a wrongdoing. This Supreme Court guideline likewise controls the phases of redirection pondering, in which the facilitator delegated by the Chief Justice is committed to give freedoms to:

1. Children to be heard about the charges

2. Guardians/Guardians to pass on issues identifying with the kid's activities and the normal type of settlement

3. Casualty/Child of Victim/Parent/Guardian to give a reaction and anticipated type of settlement.

In practice, there are still differences in the application of diversion between law enforcement officers. It is as happened in the case that occurred in decision Number 25/Pid/Sus-Anak/2018/PT MDN. In this case, the child was proven without rights and against the law in abusing Narcotics Category I, the type of methamphetamine, thus violating Article 112 paragraph (1) of Law Number 35 of 2009 concerning Narcotics. For these actions, the Public Prosecutor charged against Child 1. Xxxxx Child 2. Xxxx and Child 3. Xxxxx, with imprisonment for 2 (two) years each reduced as long as the children are in temporary detention.

For this matter, the Panel of Judges imposed action on Child I xxxxx, Child $2 \operatorname{xxxxx}$, Child $3 \mathrm{xxxxxx}$, by being returned to their respective parents and ordering Child $1 \mathrm{xxxx}$, Child 2 xxxx, Child 3 xxxxx, to be released from detention by the Temporary Child Placement Institution (LPAS) immediately after this decision was pronounced.

Tebing Tinggi District Court, Number 13/Pid.Sus-Anak/2018/PN Tbt, dated July 12, 2018, The High Court accepts that the lawful contemplations of the First Level Court which underlie its choice that the kids have been legitimately and convincingly demonstrated at real fault for perpetrating a wrongdoing "without right and illegal to mishandle Narcotics Category I sort of methamphetamine for oneself" on the grounds that these contemplations depend on lawful realities acquired at preliminary which are upheld by proof submitted at preliminary. Be that as it may, the activities and deficiencies of the youngster are relied upon to address their missteps, so it was chosen to return them to their individual guardians. Various things occurred in choice number 12/Pid.Sus-Anak/2019/PT.MDN.

In this case, a 17-year-old child has been proven to have committed violent robbery, so he is threatened with Article 365 paragraph (2) 1e, 2e of the Criminal Code. For this action, the Public Prosecutor demanded a child with a prison sentence of 6 (six) months reduced for the child was in detention. However, on February 20, 2019, the Judge of the Kisaran District Court, instead sentenced the child to imprisonment for 1 (one) year, and the decision was upheld by the Medan High Court. 
Referring to the background described above, the main issue to be discussed is how to regulate the handling of juvenile crimes through diversion in the juvenile criminal justice system?

\section{Methods}

This exploration is regulating juridical examination on the grounds that the objective of this examination is law or regularizing strategies as legitimate standards and overall sets of laws.[12] Regularizing research in this review is research that depicts or portrays exhaustively, deliberately, completely, and profoundly the guideline of taking care of adolescent wrongdoings through redirection in the adolescent criminal equity framework. This examination is elucidating on the grounds that it depicts the pertinent laws and guidelines and is related with legitimate hypotheses in their execution rehearses identified with the issues to be contemplated. The information got will be dissected by subjective investigation.

\section{Discussion}

As in the arrangements of Article 5 passage (2) of the Juvenile Justice Law requires therapeutic equity to be completed from the phase of examination to examination, it shows that the treatment of instances of youngsters in struggle with the law is settled by the technique for remedial equity. Be that as it may, practically speaking, there are contrasts in reasoning and treatment completed by policemen in taking care of instances of youngsters managing the law as portrayed behind the scenes.

In the first case, starting on Sunday, June 3, 2018, at around 23.30 WIB, witness IVAN VERNANDO and his colleagues including witness HAMDAN (both members of the National Police at the Tebing Tinggi Police) received information from someone who did not want to be identified saying that in Ridho Ibu's internet cafe on Sisingamangaraja street Bandarsono Village, Padang Hulu District, Tebing Tinggi City, there are people who are abusing the type of shabu-shabu.

After receiving this information, witness IVAN VERNANDO and witness HAMDAN investigated by visiting the place. When they arrived at the location on Monday, June 4, 2018, at around 00.50 WIB, witness IVAN VERNANDO and witness HAMDAN saw witness FAJAR SIDDIK NASUTION alias FAJAR (trial in separate case files) left the internet cafe room, Ridho Ibu and the witnesses told him to re-enter and was followed by witness IVAN VERNANDO and witness HAMDAN.

At that time, the witnesses saw Children 1. $\operatorname{xxxxxxxx}$, Children 2. $\operatorname{xxxxxxx}$, and Children

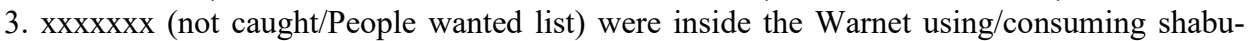
shabu type Narcotics so witness IVAN VERNANDO and witness HAMDAN immediately arrested the children and FAJAR SIDDIK NASUTION alias FAJAR while ALVIAN managed to escape, and witness IVAN VERNANDO and witness HAMDAN found evidence in the form of 1 (one) meth suction device (bong) and 1 (one) gas lighter with a needle on a table.

When a search was carried out on the bodies of the children, $\mathrm{xxxxx}$, to be precise, when the children were told to open their jackets, 1 (one) white plastic box fell, which after being opened contained 3 (three) plastic packages containing crystal powder suspected of being methamphetamine, 1 (one) sheet of cigarette tinfoil, and 1 (one) plastic pipette with a sharp tip. During the examination, FAJAR SIDDIK NASUTION alias FAJAR was found 1 (one) 
plastic package containing crystal powder suspected of having methamphetamine from inside the right pant pocket he was wearing,

When asked about the permit for possession of the methamphetamine-type Narcotics, the children and FAJAR SIDDIK NASUTION alias FAJAR could not show it and admitted that they did not have permission from the Indonesian Government or other competent authorities to possess or control the methamphetamine type of Narcotics. Furthermore, the children and FAJAR SIDDIK NASUTION a.k.a FAJAR along with the evidence brought and handed over to the Tebing Tinggi Police Narcotics Unit for processing.

After being examined, the children, SAMUEL PUTRA HARIANJA alias MUEL, admitted that they got 3 (three) plastic bags containing crystal powder suspected of having methamphetamine from KLINTOI (not caught/People's Search List) on Sunday, June 3, 2018, at around 17.30 WIB behind FAJAR SIDDIK's house. NASUTION alias FAJAR, while FAJAR SIDDIK NASUTION aka FAJAR received 1 (one) plastic wrap containing crystal powder suspected of having methamphetamine type on the ground near the trash can beside Ridho's internet cafe on Sunday, June 3, 2018, at around 21.30 WIB (UTC+7).

After weighing 3 (three) small transparent plastic packages containing crystal powder suspected of shabu-shabu type narcotics, the total gross weight is 0.52 (zero point five two) grams, and the net weight is 0.10 (zero point one zero) grams, and a pyrex glass contained crystal powder were suspected of having methamphetamine with a gross weight of 1.52 (one point five two) grams, following the Minutes of Weighing of Evidence No. 086/10087/2018 dated June 4, 2018, which was weighed by Widyana Erin Nainggolan as the Estimator / Weigher at the PT. Pegadaian Tebing Tinggi Office Branch.

Based on the Minutes of Laboratory Analysis of Narcotics Evidence No.Lab: 6385/NNF/2018 dated June 5, 2018, after a laboratory examination concluded that point A evidence was in the form of 3 (three) small transparent plastic wrappers containing crystal powder suspected of heavy shabu type narcotics. 0.52 (zero point five two) gram and net weight 0.10 (zero point one zero) gram and 1 (one) Pyrex glass containing crystal powder suspected of shabu type narcotics total gross weight 1.52 (one point five two) grams examined belong to the Children xxxxx, Etc. are Methamphetamine Positive registered in Group I (one) serial number 61 Attachment I of UURI Number 35 of 2009 concerning Narcotics.

For these actions, the Public Prosecutor charged against Child 1. Xxxxx Child 2. Xxxx and Child 3. Xxxxx, with imprisonment for 2 (two) years each reduced as long as the children are in temporary detention. Based on these demands, the Panel of Judges took action against Child 1. Xxxxx, Child 2. Xxxxx, Child 3. Xxxxx, by being returned to their respective parents and ordering Child 1. Xxxx, Child 2. Xxxx, Child 3. Xxxxx, to be released. from the detention of the Temporary Child Placement Institution (LPAS) immediately after this decision is pronounced.

Tebing Tinggi District Court, Number 13/Pid.Sus-Anak/2018/PN Tbt, dated July 12, 2018, The High Court believes that the legal considerations of the First Level Court which underlie its decision that the children have been legally and convincingly proven guilty of committing a crime "without right and against the law to abuse Narcotics Category I type shabu-shabu for oneself" because these considerations are based on legal facts obtained at trial which supported by evidence submitted at trial. However, the actions and mistakes of the child are expected to correct their mistakes, so it was decided to return them to their respective parents. Different things happened in decision number 12/Pid.Sus-Anak/2019/PT.MDN.

Initially, the child witness invited the child defendant, witnesses F. S and Dicky to commit a robbery, and at the invitation of the witness Agung, the defendant along with the witnesses Simalango and Dicky agreed then the defendant took the witness Agung riding 1 (one) unit of 
black CB150R motorcycle BK 6374 QAB while Dicky rode witness Simalango by riding 1 (one) unit of Honda Scoopy motorcycle, Black Brown color BK 3005 AFM went to look for targets and while crossing on Jalan Protocol Rejosari Dusun III Sukadamai Village, Pulo Bandring District, Asahan Regency.

The defendant along with witness Agung, witnesses Simalango and Dicky, saw the victim's witness who was on the back of witness $M$ who was riding a Honda motorcycle was also crossing the road holding 1 (one) unit of HP brand VIVO Y65 Yellow color Gold IMEI 866196031497315 with Sim Card. Then the defendant with witness Agung along with witnesses F, Simalango, and Dicky grabbed the victim's motorbike from behind the victim's witness. When they were close, witness Agung who was on a motorbike ridden by the accused child pulled forcefully on the cellphone belonging to the victim's witness by using his right hand, but the victim's witness tried to defend his cellphone.

Witness Agung kicked Witness M. in the leg who was riding the motorcycle that the victim was riding until the motorcycle lost control and fell until the VIVO Y65 cellphone belonging to the victim's witness was released and was successfully taken by Witness Agung and then the defendant and witness Agung Gunawan left the victim's witness with brought the cellphone of the victim's witness, followed by Witness Simalango who rode with Dicky who was at that time in charge of accompanying and squeezing the victim's motorbike to block the victim's motorbike when witness Agung confiscated the victim's witness' cellphone.

For this action, the Public Prosecutor demanded a child with a prison sentence of 6 (six) months reduced for the time the child was in detention. However, on February 20, 2019, the Judge of the Kisaran District Court, sentenced the child to imprisonment for 1 (one) year, and the decision was upheld by the Medan High Court instead.

Based on the two cases above, there are differences in the treatment or actions taken by law enforcement officers against children who conflict with the law. The concept of diversion was carried out by law enforcement officers in the first case, in this case, the judge of the Tebing Tinggi District Court. However, in the second case, all law enforcement officers, from the police to court judges, did not apply the diversion concept that should be the right of children in conflict with the law.

Youngsters who struggle with the law are as yet given assurance so they can live, develop, and foster after human respect and should be shielded from savagery and separation. The Juvenile Justice Law has carried out the idea of remedial equity, which has been synchronized with the arrangements of Article 1 point 6 of the Juvenile Justice Law which expresses that helpful equity is the settlement of criminal cases including the culprit, casualty, group of the culprit/casualty, and different gatherings worried to mutually look for a reasonable settlement by underscoring rebuilding to its unique state, and not counter.

The point is to secure youngsters who are culprits of wrongdoings and kids who are casualties of wrongdoing. It was following Article 28B passage (2) of the 1945 Constitution which expresses that each kid has the privilege to endurance, development and improvement, and the right to assurance of viciousness and separation. The essential job of youngsters as replacements to the standards of the country's battle has been perceived by the worldwide local area to bring forth a show that basically accentuates the situation of kids as people who should get assurance for their privileges.

The idea of redirection in the Juvenile Justice Act should be sought after in each phase of the legal executive, beginning from the examination, arraignment, and assessment in court. What's more, the job of different establishments (like Social Welfare Organizing Institutions, and Community Counselors) is important to help the acknowledgment of remedial equity, particularly for kid guilty parties. 
As per the creator, when helpful equity is completed, the kid culprits of wrongdoing are under the management of the local area so the local area has a sense of security and certain about the job of the adolescent equity framework, including schools, families, and local area organizations to forestall wrongdoing, increment social bonds and reintegration. The culprits, casualties, the local area, and the adolescent equity experts' job is exceptionally expected to further develop local area insurance. Culprits should be involved helpfully in creating capabilities and therapeutic exercises in the program in a decent way, creating inner control and responsibility with friends and kids' associations.

Victims provide worthy input to continue the mission of protecting society from fear and the need for broader behavioral control and protecting other victims of crime. The community contributes guidance to perpetrators, acts as a mentor and provides input to the judiciary regarding background information on the crime occurrence.

Juvenile justice professionals develop incentive scales and ensure that offenders fulfill their supervisory obligations, assisting schools and families in their efforts to monitor and keep offenders in the community. Markers in helpful adolescent equity can be seen from the jobs of culprits, casualties, the local area, and adolescent equity experts. Each capacity is as per the following:

1. Culprits: dynamic culprits to reestablish misfortunes to casualties and the local area. He should confront the person in question/casualty's representative;2. Casualties: effectively associated with all phases of the interaction and assume a functioning part in intervention and partake in deciding approvals for culprits;

2. Local area: required as a middle person in creating local area benefits and giving open positions to culprits as a type of reparative commitments, helping casualties and supporting the satisfaction of the culprits' commitments;

3. Experts: working with intervention, giving certifications to helpful execution, creating imaginative/remedial local area administration choices, including local area individuals all the while, teaching the local area.

The author argues, based on this, imposing imprisonment on child perpetrators who commit minor to moderate crimes is not a fair solution for child offenders. According to the author, because the imposition of imprisonment is against human rights, both in terms of religion and in terms of positive law, the government and society should focus more on victims who are also entitled to compensation and restitution as well as care and guidance for the perpetrators.

As indicated by the creator, as a work to secure casualties of kid violations as culprits and furthermore as a work to keep culprits from rehashing their mix-ups, the public authority can utilize the twofold track framework strategy is a two-way arrangement of authorizations in criminal law, in particular the sort of criminal endorses from one viewpoint and kinds of activity sanctions on the other. Criminal assents depend on the essential thought of why discipline is held, while activity sanctions depend on the fundamental thought of "what is the discipline for."

The author argues, criminal sanctions for children who conflict with the law, so if there are victims of the actions of the child perpetrators, they only need to be punished with social work sanctions or returned to parents as regulated in Law Number 23 of 2002 concerning Child Protection, in addition, to being given social work sanctions, child perpetrators who conflict with the law are also given action sanctions, in the form of care and guidance for child perpetrators who conflict with the law so that they can return to being good human beings and provide compensation to the victim or compensation. 
Treatment for child perpetrators who conflict with the law that they can return to being good human beings because generally, child perpetrators have experienced trauma or social errors when the child perpetrator was still young. Then in addition to child perpetrators are given psychological counseling therapy, child perpetrators are also required to provide compensation to the victim or compensation.

The provision of compensation here is to create corrective justice, namely justice that builds equality, meaning that every act of a person must be judged in balance with his actions. The actions of child perpetrators are wrong deeds because they can traumatize the victim so that to create justice for the victim, the child perpetrator should be given action sanctions in the form of providing compensation to the victim or compensation.

Compensation is a kind of compensation (materially) from child perpetrators to their victims. If the attention from the government and the concern from the community is immaterial, the compensation given by child perpetrators to victims is more material.

In formal juridical terms, the remuneration from kid culprits to their casualties has been directed in the Criminal Code and the Criminal Procedure Code. Article 14. a section (1) of the Criminal Code (Moeljatno's interpretation) states:

Assuming the adjudicator forces most extreme detainment of one year, barring substitute imprisonment, in his judgment, he may likewise arrange that the sentence shouldn't be completed. But on the off chance that in the future there is an adjudicator's choice that decides various things on the grounds that the convict carries out a criminal demonstration before the probation time frame indicated in the previously mentioned request terminates, or on the grounds that the convict during the probation time frame doesn't meet the extraordinary conditions that not really set in stone in that occasion.

In Article 14. c paragraph (1) of the Criminal Code (Moeljatno's translation) states:

"In the order referred to in Article 14.a. unless a fine is imposed, in addition to stipulating the general condition that the convict will not commit a criminal act, the judge may assign a specific requirement that the convict within a certain period, which is shorter than his probationary period, must compensate all or part of the loss caused by the criminal act."

Based on the two formulations of the article above, it can be concluded that if the child perpetrator is only sentenced to probation by the judge, because in the Criminal Code there is no general minimum provision so that the judge can impose the lightest punishment for child offenders, including this probation, the judge can also order the child perpetrator to compensate the victim. The compensation given to the victim can be in the form of reimbursement for treatment costs while the victim is hospitalized or other charges for the needs of the victim's recovery, for example, the fee of a psychiatrist.

Apart from that, it is known that current criminal policy (criminal policy) in legislative policies, especially criminal policies in applicative measures are needed and urgent in nature. There are several aspects why this policy needs to be formulated, namely: First, it is hoped that as far as possible it is expected to relatively suppress disparities in sentencing (disparity of sentencing) to similar cases or cases, which are almost identical, and the provisions of the offenses violated are relatively the same. In essence, Molly Cheang's disparity is the application of unequal punishment to the same crime (same offense) or to criminal acts whose dangerous nature can be compared (offenses of comparable seriousness) without a clear justification.[13]

Sentencing guidelines in legislative policies, so judges in terms of implementing regulations as applicative policies can impose more just, humane punishments and have juridical, moral justice, and social justice signs. Concretely, the logical consequence of this aspect is that the judge's decision or court decision has expected to be closer to justice that 
reflects the values that live in society. However, the reality is that in Indonesia, there are no sentencing guidelines that can serve as a barometer and catalyst for judges. This aspect is emphasized by Sudarto as follows: "Our Criminal Code does not contain general criminal guidelines (straftoemetingsleiddraad), which are guidelines made by legislators that consist of principles that need to be considered by judges in imposing criminal penalties.

This dimension is identical to the legal situation in Singapore, where this aspect is described in more detail by Molly Cheang that: "The conventional law as communicated in our criminal law gives gigantic optional capacity to the appointed authority without direction concerning how that power is to be worked out. The law by and large blueprints a wide scope of conceivable outcomes. The assembly regularly does little than build up an upper and lower limit ".[15]

Second, the sentencing guidelines provide room for movement, dimension, and actualization for judges in explaining the law as a legislative policy following the nuances desired by the legislators. This aspect is crucial because the legislative testament is strategic and decisive. After all, errors in legislative policies will have a higher effect on applicable policies implemented in the field. Therefore, of course, synchronization, transparency, and juridical background are needed regarding the nature of law, and what legislators want to be concretized so that judges, as an applicative policy, do not misapply and embody the law.

Third, the sentencing guidelines provide and function as a catalyst to become a "safety valve" for judges in imposing criminal penalties on defendants so that judges can make decisions that are more fair, wise, humane, and relatively adequate for the mistakes that have been made by the defendant. Therefore, the sentencing guidelines are hoped can find justice that can be accepted by all parties, and reflected in the value of legal certainty (rechtszekerheids) imposed by the judge in his decision.

With such benchmarks, the essence of "punishment philosophy" is also oriented to the "model of justice" to be achieved in a Criminal Justice System. Concretely, how judges as controllers of applicable policies in terms of making decisions are also oriented to the theoretical dimension and must also refer to the values of justice to be achieved by all parties.

Furthermore, Sue Titus Reid said that this component is the "model of equity" as an advanced support for discipline. This model is known as the equity approach or the simply desert model, which depends on two speculations (destinations) of discipline, in particular anticipation and retaliation. The reason for retaliation accepts that violators will be decided with suitable approvals for the wrongdoings they have perpetrated. It is viewed as that appropriate assents will keep the pre-criminal from carrying out violations again and furthermore keep others from perpetrating wrongdoings.[16]

Likewise, after the court decision is handed down and all legal remedies have been carried out and finally the decision has permanent legal force, the criminal procedure law stipulates the main points of how to implement and supervise the decision. What is regulated in the criminal procedural law are the ways that must be taken in upholding legal order in society, but at the same time also aims to protect the human rights of each individual, both victims, and violators of the law.

The relation between the Criminal Procedure Code and the Juvenile Court is that the child must still be in the concept of human rights which is specifically called the Rights of the Child. Children's rights are human rights when in conflict with the law. So, the judge's decision must contain the values of restorative justice. The role of judges as critics of the law is unavoidable. Judges are not only required to read word for word from an article but also required to explore the meaning of an article so that the application of an article has the value of justice. Judges are also asked to be able to use their abilities in the field of empirical law. 
Able to apply the theory of legal interpretation and legal discovery well so that when deciding a case by applying an article, the article used or applied has fulfilled a sense of justice.

\section{Conclusion}

Courses of action for dealing with adolescent violations through redirection in the adolescent criminal equity framework are contained in Article 5 section (1) of Law Number 11 of 2012 concerning Juvenile Justice, in particular with a helpful equity approach which is thought to be the latest shift from the different models and components that work in the criminal equity framework in managing criminal cases, one of which is kid wrongdoing. Nonetheless, by and by, there are still court choices that force jail sentences on youngsters, despite the fact that the violations submitted by the kid can be applied with social work punishments or training that focuses on the kids' privileges to get back to being acceptable kids.

\section{References}

[1] Marsaid, Legal Protection of Children in the Perspective of Islamic Law (Maqasid AsySyari'ah), Palembang: NoerFikri, 2015.

[2] L.J. van Apeldoorn, Introduction to Law, Translation, Translated By: Oetarid Sadino, Jakarta: Pradnya Paramitha, 2009, p. 11.

[3] Philipus M. Hadjon, Legal Protection for the People of Indonesia, Surabaya: PT. Science Development, 1987, p. 1-2

[4] Article 1 number 1 of the Law of the Republic of Indonesia Number 39 of 1999 concerning Human Rights (State Gazette of the Republic of Indonesia of 1999 Number 165, Supplement to the State Gazette of the Republic of Indonesia Number 3886).

[5] Jimly Asshiddiqie, The Idea of a Social Constitutional Constitution and the Constitutionalization of Civil Society Social Life, Jakarta: LP3ES 2015, p. 85.

[6] M. Sofyan Lubis, Miranda Rule Principles, Rights of Suspects before Examination, Yogyakarta: Pustaka Yustisia, 2010, p. 21.

[7] Yesmil Anwar and Adang, Criminal Justice System (Concepts, Components and Implementation in Law Enforcement in Indonesia), Bandung: Widya Padjadjaran, 2009 , p. 35.

[8] Gatot Supramono, Juvenile Court Procedural Law, Jakarta: Djambatan, 2007, p. 13

[9] Rufinus Hotmaulana Hutauruk, Combating Corporate Crime Through a Restorative Approach. Massachusetts-USA: Lexington, 2013, p. 95.

[10] Marlina, Introduction to the Concept of Diversion and Restorative Justice, Medan: USU Press, 2010, p. 10.

[11] JCT Simorangkir et al, Legal Dictionary, Jakarta: Sinar Graphic, 2008, p. 38.

[12] Soerjono Soekanto and Sri Mamudji, Normative Legal Research-A Brief Overview, Jakarta: Rajawali Press, 2007, p. 10.

[13] Molly Cheang, Disparity of Sentencing, Singapore Malaya Law, Journal, PTE Ltd., 1977 , p. 2.

[14] Sudarto, Capita Selecta Criminal Law, Bandung: PT Alumni, 1981, pp. 79—80

[15] Molly Cheang, Disparity of Sentencing, Singapore Malaya Law, Journal, PTE Ltd., 1977, p. 4 
